\title{
Chemical composition and biological activity of cardoon (Cynara cardunculus L. var. altilis) seeds harvested at different maturity stages
}

\author{
Filipa Mandim ${ }^{\mathrm{a}, \mathrm{b}}$, Spyridon A. Petropoulos ${ }^{\mathrm{c}, *}$, José Pinela ${ }^{\mathrm{a}}$, Maria Inês Dias ${ }^{\mathrm{a}}$, \\ Kyriakos D. Giannoulis $^{c}$, Marina Kostić ${ }^{\mathrm{d}}$, Marina Soković ${ }^{\mathrm{d}}$, Beatriz Queijo ${ }^{\mathrm{a}}$, \\ Celestino Santos-Buelga ${ }^{b}$, Isabel C.F.R. Ferreira ${ }^{a}$, Lillian Barros ${ }^{a, "}$ \\ ${ }^{a}$ Centro de Investigação de Montanha (CIMO), Instituto Politécnico de Bragança, Campus de Santa Apolónia, 5300-253 Bragança, Portugal \\ ${ }^{\mathrm{b}}$ Grupo de Investigación en Polifenoles (GIP-USAL), Facultad de Farmacia, Universidad de Salamanca, Campus Miguel de Unamuno s/n, 37007 Salamanca, Spain \\ ${ }^{\mathrm{c}}$ University of Thessaly, Department of Agriculture, Crop Production and Rural Environment, 38446 N. Ionia, Volos, Greece \\ ${ }^{\mathrm{d}}$ Institute for Biological Research "Siniša Stanković"- National Institute of Republic of Serbia, University of Belgrade, Bulevar despota Stefana 142, Belgrade, Serbia
}

\section{A R T I C L E I N F O}

\section{Keywords:}

Cynara cardunculus (L.)

Cardoon seeds

Maturity stage

Phenolic composition

Bioactive properties

Cytotoxicity

\begin{abstract}
A B S T R A C T
Cardoon seeds collected in Greece at four different maturity stages (samples S1 to S4) were analysed in terms of chemical composition and in vitro bioactivities. The content of phenolic compounds (six compounds in total) increased with increasing maturity, and 3,5-O-dicaffeyolquinic (14.8-33.8 mg/g extract) acid was the compound detected in higher abundance. Mature seeds (sample S4) also revealed the highest content in lipids (23 g/100 g extract) and tocopherols $(29.62 \mathrm{mg} / 100 \mathrm{~g} \mathrm{dw})$ and demonstrated the highest cytotoxic (GI 50 of $97-216 \mu \mathrm{g} / \mathrm{mL}$ ) and anti-inflammatory ( $\mathrm{IC}_{50}=148 \mu \mathrm{g} / \mathrm{mL}$ ) activities, and capacity to inhibit the formation of thiobarbituric acid reactive substances (TBARS) ( $\mathrm{IC}_{50}=5 \mu \mathrm{g} / \mathrm{mL}$ ). Cardoon seed hydroethanolic extracts also revealed high antibacterial and antifungal potential, particularly samples S3 and S1, respectively. This study proved the multifaceted potential associated with valorisation of cardoon seeds, while their biological and chemical composition can be influenced by the maturity stage.
\end{abstract}

\section{Introduction}

Cynara cardunculus L., commonly known as cardoon, is a widely distributed species with high abundance in the Mediterranean basin, as a result of its high resistance to variations in climate conditions so characteristic of the climate of the Mediterranean region (e.g. resistance to extreme temperatures, water stress, and soils with variable $\mathrm{pH}$ or high salinity). It is an herbaceous species from the Asteraceae family and comprises three cultivar groups: the cultivated cardoon or var. altilis DC., the wild cardoon or var. sylvestris (Lamk) Fiori, and the globe artichoke or var. scolymus (L.) Fiori (Bartocci, Bidini, Cotana, \& Fantozzi, 2016; Zayed, Serag, \& Farag, 2020). It was in Sicily that the domestication of globe artichoke began, spreading to the rest of the world, particularly to Mediterranean countries, to Central Europe and the United States (Conceição, Martins, Alvarenga, Dias, Lamy, Garrido, \& Duarte, 2012; Gostin \& Waisundara, 2019). The domesticated cardoon is the variety of cardoon that is consumed in several recipes in the Mediterranean basin due to its rich nutritional composition and health-promoting effects (Conceição et al., 2012).

Cardoon is well known for its variety of pharmacological and nutritional properties, as well as its multifaceted industrial applications. It is consumed and used in traditional medicine for the treatment of liver diseases and as an antidiabetic, cardiotonic, choleretic, and antihemorrhodial agent (Conceição et al., 2012; Gostin \& Waisundara, 2019; Salem et al., 2017). Scientific evidence has attributed lipidlowering, antioxidant, anti-inflammatory (Chihoub et al., 2019; Salekzamani, Ebrahimi-Mameghani, \& Rezazadeh, 2019), antimicrobial, and cytotoxic (Chihoub et al., 2019; Conceição et al., 2012) effects to this plant. Furthermore, in the last few years, the economic and commercial interest associated with this species has been growing due to its diverse industrial applications, such as the production of paper pulp, energy (including biodiesel), and lignocellulosic biomass, and also as a food ingredient for the production of edible oils and some types of cheese (Almeida \& Simões, 2018; Barbanera et al., 2021; Bartocci et al., 2016).

There are several reports that refer to the wide variety of bioactive

\footnotetext{
* Corresponding authors.

E-mail addresses: spetropoulos@uth.gr (S.A. Petropoulos), lillian@ipb.pt (L. Barros).
} 
compounds present in the different plant tissues of Cynara cardunculus. The various plant parts are a rich source of important dietary components, such as fibre, minerals, and inulin, as well as phenolic compounds, mainly derived from caffeoylquinic and dicaffeoylquinic acids, anthocyanins, sesquiterpene lactones, and flavonoids such as luteolin and apigenin derivatives (Amira et al., 2018; Brás, Guerreiro, Duarte, \& Neves, 2015; Petropoulos, Pereira, Tzortzakis, Barros, \& Ferreira, 2018; Petropoulos, Pereira, Ntatsi et al., 2018). Moreover, there are several studies that demonstrated through analytical methodologies the biological potential of this species, e.g. antioxidant (Petropoulos, Pereira, Tzortzakis et al., 2018; Petropoulos, Pereira, Ntatsi et al., 2018), antibacterial (Mandim, Dias et al., 2020; Scavo et al., 2019), antifungal (Petropoulos et al., 2019; Scavo et al., 2019), anti-tumour (do Carmo, Pressete, Marques, Granato, \& Azevedo, 2018), and anti-inflammatory properties (Kammoun et al., 2010; Mandim et al., 2021). Cardoon seeds are mostly explored for edible oil extraction (Mirpoor, Giosafatto, \& Porta, 2021). Although there are previous works describing the chemical composition and some bioactivities of cardoon seeds, which have a composition rich in nutrients and bioactive compounds of pharmacological interest (Durazzo et al., 2013; Mandim, Dias et al., 2020; Petropoulos et al., 2019), studies with samples obtained at different maturity stages are very scarce and can be an important contribution to the proper use of this plant material and, simultaneously, add economic value to this species.

The chemical composition and associated biological properties of the plant species are influenced by several factors, including genetic background, plant part, growing location, and maturation stage (Petropoulos et al., 2019). The study of the influence of these factors is of great important for the proper use and application of the raw materials of plant origin, also allowing the reduction of biowaste and the economic valorisation of all constituents, following a circular economy concept. Considering the scarcity of information in the literature regarding the effect of the maturation stage on the chemical composition and bioactive properties of cardoon seeds, the aim of this study was to evaluate its impact on seeds collected in central Greece at four different harvest times. The results will elucidate how the chemical composition and bioactive properties of cardoon seeds are affected by the maturity stage, but also add value to this plant raw material, which so far has been manly used for oil extraction, through the diversification of its potential applications in the food and pharmaceutical industries, among others.

\section{Materials and methods}

\subsection{Plant material}

Seed samples of Cynara cardunculus var. altilis DC cv. Bianco Avorio (Fratelli Ingegnoli Spa, Milano, Italy) were collected during the growing period of 2017-2018 from the experimental field of the University of Thessaly in Velestino, in central Greece (22.756E, 39.396N). Seeds were collected at different flowering stages and principal growth stages (PGS), according to the Biologische Bundesanstalt, Bundessortenamt, CHemische Industrie (BBCH) scale (Archontoulis, Struik, Vos, \& Danalatos, 2010). In particular, four samples were analysed, corresponding to four different harvesting dates and principal growth stages (Table 1): S1 corresponds to PGS 6/7 (harvest: 12 June 2018), S2 corresponds to PGS 7/8 (harvest: 4 July 2018), S3 corresponds to PGS 7/8 (harvest: 18 July 2018), and S4 corresponds to PGS 8 (harvest: 9 August 2018). The plant material was prepared and stored according to the procedure previously described in our previous work (Mandim et al., 2021). The samples were freeze-dried (Sublimator model EKS, Christian Zirbus Co., Germany), powdered with a domestic grinder, and sieved $(0.85-1 \mathrm{~mm}$ sieve size) to obtain a fine powder. The samples were stored protected from light at $-80^{\circ} \mathrm{C}$.
Table 1

Main characteristics of Cynara cardunculus L. var altilis seed samples collected at different maturity stages.

\begin{tabular}{|c|c|c|c|}
\hline $\begin{array}{l}\text { Sample } \\
\text { code }\end{array}$ & $\begin{array}{l}\text { Harvesting } \\
\text { time }\end{array}$ & $\begin{array}{l}\text { Maturity } \\
\text { stage }\end{array}$ & Main characteristics \\
\hline S1 & $\begin{array}{l}\text { 12 June } \\
2018\end{array}$ & PGS $6 / 7$ & $\begin{array}{l}\text { End of flowering of primary heads and } \\
\text { beginning of flowering of second order } \\
\text { heads-seeds are full sized in first and } \\
\text { second order heads }\end{array}$ \\
\hline S2 & 4 July 2018 & PGS $7 / 8$ & $\begin{array}{l}\text { Primary heads start to turn yellow- } \\
\text { florets become visible-seeds in all heads } \\
\text { are full sized }\end{array}$ \\
\hline S3 & 18 July 2018 & PGS $7 / 8$ & $\begin{array}{l}\text { Primary heads start to turn yellow- } \\
\text { florets become visible-seeds in all heads } \\
\text { are full sized }\end{array}$ \\
\hline S4 & $\begin{array}{l}9 \text { August } \\
2018\end{array}$ & PSG 8 & Seeds fully ripened and start to disperse \\
\hline
\end{tabular}

\subsection{Chromatographic analysis of chemical constituents}

\subsubsection{Fatty acids}

The lipid fraction was determined through extraction with petroleum ether, at $120{ }^{\circ} \mathrm{C}$ and using a Soxhlet extraction apparatus, according to the recommended by Association of Official Agricultural Chemists (AOAC) procedures (AOAC, 2016). The obtained lipid fraction was subjected to a transesterification process and the fatty acids composition was analysed by Gas-liquid Chromatography (GC 1000, DANI instruments, Contone, Switzerland) with a split/splitless injector and coupled to a flame ionization detector (FID) according to the analytical conditions described in our previous work (Petropoulos, Pereira, Ntatsi et al., 2018). The identification and quantification were performed using Clarity DataApex 4.0 software (DataApex, Prague, Czech Republic) by comparison of the retention times of the Fatty Acid Methyl Ester (FAME) peaks of samples with those of the commercial standards (reference standard mixture 47885-U; Sigma-Aldrich, St. Louis, MO, USA). The results were presented as relative percentage of each fatty acid.

\subsubsection{Tocopherols}

The tocopherols of cardoon seeds $(500 \mathrm{mg})$ were extracted with a hexane solution of butyl-hydroxy-toluene $(10 \mathrm{mg} / \mathrm{mL} ; 100 \mu \mathrm{L})$ and tocol (internal standard (IS), $400 \mu \mathrm{L}$ at $50 \mathrm{mg} / \mathrm{mL}$ ), according to the procedure described in the previous work by Mandim, Dias et al. (2020). The obtained solution was homogenised using a vortex mixing with methanol $(4 \mathrm{~mL})$, followed by hexane $(4 \mathrm{~mL})$, and a saturated $\mathrm{NaCl}$ aqueous solution $(2 \mathrm{~mL}$ ). After centrifugation (5 $\mathrm{min}$ at $4000 \mathrm{~g}$ ), the clear upper layer was transferred to a vial. After their dryness under a nitrogen stream and their re-solution in $n$-hexane $(2 \mathrm{~mL})$, the samples were analysed by high performance liquid chromatography (HPLC, Knauer, Smartline system 1000, Berlin, Germany) coupled to a fluorescence detector (FP-2020, Jasco, Easton, USA) with excitation at $290 \mathrm{~nm}$ and emission at $330 \mathrm{~nm}$, according to the conditions previously described (Pereira, Barros, Carvalho, Santos-Buelga, \& Ferreira, 2015). The identification and quantification were implemented via the Clarity 2.4 software (DataApex, Podohradska, Czech Republic), using the internal standard method and by comparison with commercial standards $(\alpha, \beta, \gamma$, and $\delta$ isoforms). Results were expressed in mg per $100 \mathrm{~g}$ of dry weight.

\subsubsection{Organic acids}

The organic acids were extracted with metaphosphoric acid (4\%) under protection from light according to the procedure described in our previous work (Mandim et al., 2019). The samples were analysed by Ultrafast Liquid Chromatography (UPLC-PDA, Shimadzu 20A series Kyoto, Japan) coupled to a Diode Array Detector (UFLC-PDA, Shimadzu Corporation, Kyoto, Japan). The identification of organic acids was performed through the comparison of the spectra and the retention times with commercial standards (oxalic, quinic, malic, ascorbic, citric, and fumaric acids purchased from Sigma-Aldrich, St Louis, MO, USA). 
For the quantification were used the calibration curves of the commercial standards and the area of peaks. The results were analysed through the LabSolutions Multi LC-PDA software (Shimadzu Corporation, Kyoto, Japan) and were expressed in $g$ per $100 \mathrm{~g}$ of dry weight.

\subsubsection{Free sugars}

To the determination of the free sugars of cardoon seeds, the samples were extracted with a aqueous ethanol (EtOH: $\mathrm{H}_{2} \mathrm{O}, 80: 20, v / v, 40 \mathrm{~mL}$ ) and the internal standard melezitose (IS, $5 \mathrm{mg} / \mathrm{mL}$ ) at $80{ }^{\circ} \mathrm{C}$ for $90 \mathrm{~min}$. The solution was centrifuged at $15,000 \mathrm{~g}$ for $10 \mathrm{~min}$ and the supernatant was concentrated under reduced pressure (rotary evaporator Büchi R210, Flawil, Switzerland). The obtained solution was defatted with ethyl ether (10 mL, three times) and the solid residues were dissolved in water to a final volume of $5 \mathrm{~mL}$. The free sugars content was analysed by HighPerformance Liquid Chromatography (HPLC, Knauer Smartline 2300, Knauer, Berlin, Germany), coupled to a refractive index detector (RI detector, Knauer Smartline 2300, Knauer, Berlin, Germany) following the procedure previously described (Dias et al., 2015). The identification was performed through the comparison of the retention times with the commercial standards (D- $(-)$-fructose, D- $(+)$-sucrose, D- $(+)$-glucose, D$(+)$-trehalose, and D-(+)-raffinose pentahydrate purchased from SigmaAldrich (St. Louis, MO, USA). For the quantification, the areas of the peaks were compared with the calibration curves of the commercial standards. The results were analysed using the Clarity 2.4 software (DataApex, Prague, Czech Republic) and were expressed in $\mathrm{g}$ per $100 \mathrm{~g}$ of dry weight.

\subsubsection{Phenolic compounds}

2.2.5.1. Extraction methodology. Each sample (1.5 $\mathrm{g}$ of fine powder) was extracted under vigorous stirring (150 rpm) with a hydroethanolic mixture (EtOH/ $\left.\mathrm{H}_{2} \mathrm{O}, 80: 20, v / v ; 30 \mathrm{~mL}\right)$, at room temperature for $1 \mathrm{~h}$. The extracts were filtered through Whatman paper No. 4, and the obtained residue was re-extracted under the same conditions. The combined extracts were concentrated under reduced pressure with a water bath at $40{ }^{\circ} \mathrm{C}$ (rotary evaporator Büchi R-210, Flawil, Switzerland). The aqueous phase was frozen and lyophilized (FreeZone 4.5, Labconco, Kansas City, MO, USA) for further analysis.

2.2.5.2. HPLC-DAD-ESI/MS ${ }^{n}$ analysis. The lyophilized seeds extracts were re-dissolved in $\mathrm{EtOH} / \mathrm{H}_{2} \mathrm{O}(20: 80, v / v)$ in order to obtain solutions with a concentration of $10 \mathrm{mg} / \mathrm{mL}$ and filtered through a $0.22 \mu \mathrm{m}$ nylon syringe filter. The phenolic compounds composition was determined by HPLC coupled to a diode array detector and electrospray ionization mass spectrometry (HPLC-DAD-ESI/MS) and according to the procedure described by Bessada, Barreira, Barros, Ferreira, and Oliveira (2016). The tentative identification of compounds was based on the obtained information (retention times and UV-Vis and mass spectra) and comparison with commercial standards and the available literature information. The quantification was performed through the determination of the area of the obtained peaks and their comparison with the calibration curves of most similar standards commercially available (chlorogenic acid: $\mathrm{y}=208604 \mathrm{x}+173056, \mathrm{R}^{2}=0.9995 ; \mathrm{LOD}=0.20 \mu \mathrm{g} / \mathrm{mL} ; \mathrm{LOQ}=$ $0.68 \mu \mathrm{g} / \mathrm{mL}$ ). Final results were expressed in $\mathrm{mg}$ per $\mathrm{g}$ of extract.

\subsection{Evaluation of bioactive properties}

The evaluation of the different bioactive properties was performed with the cardoon seeds extracts obtained as described in Section 2.2.5.1.

\subsubsection{Antioxidant activity}

The antioxidant activity of the extracts was tested through their ability to inhibit the formation of thiobarbituric acid reactive substances (TBARS) and the oxidative haemolysis (OxHLIA). The commercial antioxidant Trolox was used as positive a control.
2.3.1.1. Inhibition of TBARS formation. The ability of the extracts to inhibit the TBARS formation was evaluated according to the procedure described in our previous work Mandim, Dias et al. (2020). The extracts were re-dissolved in $\mathrm{H}_{2} \mathrm{O}$ at $5 \mathrm{mg} / \mathrm{mL}$ and the range of tested concentrations $(1.6-416 \mu \mathrm{g} / \mathrm{mL})$ was obtained by successive dilutions. The results were presented as the concentration of extract that inhibited the oxidative process by $50 \%\left(\mathrm{IC}_{50}, \mu \mathrm{g} / \mathrm{mL}\right)$.

2.3.1.2. Inhibition of oxidative haemolysis. The ability of the extracts to inhibit oxidative haemolysis of ovine erythrocytes was evaluated according to the procedure previously described by Mandim et al. (2019). An erythrocyte solution $(2.8 \%, v / v)$ prepared in phosphate-buffered saline (PBS, pH 7.4) was mixed with either: i) extract solution (4.68-600 $\mu \mathrm{g} / \mathrm{mL})$; ii) PBS (control); iii) distilled water; or iv) trolox (7.81-250 $\mu \mathrm{g} / \mathrm{mL}$ PBS). After pre-incubation at $37^{\circ} \mathrm{C}$ for $10 \mathrm{~min}$ with shaking, the oxidant $2,2^{\prime}$-azobis(2-methylpropionamidine) dihydrochloride $(160 \mathrm{mM})$ was added and the optical density was measured at $690 \mathrm{~nm}$ over time until complete haemolysis. The results were expressed as the extract concentration that maintained $50 \%$ of the erythrocytes population intact $\left(\mathrm{IC}_{50}, \mu \mathrm{g} / \mathrm{mL}\right.$ ) after $\Delta t$ of 60 and $120 \mathrm{~min}$.

\subsubsection{Cytotoxic and hepatotoxic activities}

The cardoon seeds extracts were dissolved in water and successively diluted to obtain the stock solutions $(0.125-8 \mathrm{mg} / \mathrm{mL})$. The concentrations of extracts were incubated with the tested cell lines $(190 \mu \mathrm{L}$, 10,000 cells $/ \mathrm{mL}$ ) and the final concentrations tested were $6.25-400 \mu \mathrm{g} /$ $\mathrm{mL}$. The cytotoxic potential was evaluated using the sulforhodamine $\mathrm{B}$ assay (Mandim et al., 2021) using four human tumour cell lines: cervical carcinoma (HeLa), hepatocellular carcinoma (HepG2), breast carcinoma (MCF-7), and non-small cell lung cancer (NCI-H460) (Leibniz-Institute DSMZ - German Collection of Microorganisms and Cell Cultures GmbH). A non-tumour porcine liver primary culture (PLP2) was also used for the evaluation of the hepatotoxic potential. This culture was established by the authors in the laboratory using porcine liver tissue. Liver tissue was immersed in Hank's balanced salt solution (HBSS) containing $100 \mathrm{U} / \mathrm{mL}$ penicillin and $100 \mu \mathrm{g} / \mathrm{mL}$ streptomycin, for adequate tissue washing, and $1 \times 1 \mathrm{~mm}^{3}$ explants were obtained. Subsequently, the explants were transferred to $25 \mathrm{~cm}^{2}$ flasks, where RPMI-1690 medium supplemented with L-glutamine, penicillin $(100 \mathrm{U} / \mathrm{mL})$, streptomycin $(100 \mu \mathrm{g} / \mathrm{mL})$, fetal bovine serum (10\%), and non-essential amino acids $(2 \mathrm{mM})$ were added. The flasks were incubated at $37{ }^{\circ} \mathrm{C}$ with $5 \% \mathrm{CO}_{2}$ and humid atmosphere. During the incubation process, cell proliferation was observed using a phase contrast microscope and the culture medium was renewed approximately every two days. After reaching their maximum potential, the cells were used. Ellipticine (Sigma-Aldrich, St. Louis, MO, USA) was used as a positive control, and the cell suspension without any sample was the negative control. Results were expressed as extract concentration responsible for $50 \%$ of cell growth inhibition ( $\mathrm{GI}_{50}, \mu \mathrm{g}$ / $\mathrm{mL})$.

\subsubsection{Anti-inflammatory potential}

For the evaluation of the anti-inflammatory potential of cardoon seeds, the procedure previously described by Mandim et al. (2019) was followed. This method measures the extracts capacity to inhibit the lipopolysaccharide (LPS)-induced nitrite oxide (NO) production using a murine macrophage cell line (RAW 264.7). The extracts were dissolved in water at a final concentration of $8 \mathrm{mg} / \mathrm{mL}$ which was subjected to successive dilutions in order to obtain the final concentrations tested $(6.25-400 \mu \mathrm{g} / \mathrm{mL})$. Dexamethasone (Sigma-Aldrich, Saint Louis, MO, USA) was used as positive control, and as negative control was used the samples without LPS (Sigma-Aldrich, Saint Louis, MO, EUA). Results were presented as the extracts concentration that causes $50 \%$ of NO production inhibition ( $\mathrm{IC}_{50}, \mu \mathrm{g} / \mathrm{mL}$ ). 


\subsubsection{Antimicrobial activity}

For the evaluation of the antimicrobial potential, the procedure previously described by Mandim et al. (2021) was followed. Cardoon extracts were re-dissolved in 5\% dimethyl sulfoxide (DMSO) (SigmaAldrich, Saint Louis, MO, EUA) and further diluted to obtain the concentrations tested. The antibacterial capacity was evaluated by using Gram-positive (Bacillus cereus (food isolate), Staphylococcus aureus (ATCC 11632) and Listeria monocytogenes (NCTC 7973)) and Gramnegative (Escherichia coli (ATCC 25922), Enterobacter cloacae (ATCC 35030) and Salmonella Typhimurium (ATCC 13311)) bacteria. The antifungal activity was tested against the micromycetes Aspergillus fumigatus (human isolate), Aspergillus versicolor (ATCC 11730), Aspergillus niger (ATCC 6275), Penicillium funiculosum (ATCC 36839), Penicillium ochrochloron (ATCC 9112) and Penicillium verrucosum var. cyclopium (food isolate)). All microorganisms are deposited at Mycological laboratory, Department of Plant Physiology, Institute for Biological Research "Siniša Stanković" - National Institute of Republic of Serbia, University of Belgrade, Serbia. The commercial antibiotics ampicillin and streptomycin, and the fungicides bifonazole and ketoconazole were used as positive controls (all acquired from Sigma-Aldrich, St. Louis, MO, USA), while 5\% DMSO was used as negative control. The results were expressed as minimal inhibitory (MIC), bactericidal (MBC) or fungicidal (MFC) concentrations $(\mathrm{mg} / \mathrm{mL})$.

\subsection{Statistical analysis}

All the described experiments were executed in triplicate. Results were presented as the mean value \pm standard deviation (except for antimicrobial activity), both calculated using Microsoft Excel. The obtained results were analysed using SPSS Statistics (IBM SPSS Statistics for Mac OS, Version 26.0; IBM Corp., Armonk, NY, USA). The results were analysed by a one-way analysis of variance (ANOVA) followed by a Tukey's HSD test for means comparison $(\alpha=0.05)$. A Student's $t$-test was applied when only two samples were compared.

\section{Results and discussion}

\subsection{Composition in tocopherols}

The results regarding the composition and content of tocopherols in cardoon seeds in relation to their maturity stage are presented in Table 2. $\alpha$-Tocopherol was the only detected isoform and its concentration increased significant ( $p$-value $<0.05$ ) throughout the maturation process. The immature sample $(\mathrm{S} 1,2.20 \mathrm{mg} / 100 \mathrm{~g} \mathrm{dw})$ had a content 13.5 times lower than that detected in the sample with the highest maturity grade (S4, $29.62 \mathrm{mg} / 100 \mathrm{~g} \mathrm{dw}$ ). Statistically significant differences ( $p$-value $<0.05$ ) were only observed after the S2 maturation stage. The higher content of tocopherols in samples with longer maturity stages may be associated with the environmental condition of the sampling period, since the S4 sample was exposed to higher temperatures, and subjected to greater sunlight exposure (Mandim, Giannoulis, Santos-Buelga, Ferreira, \& Barros, 2020). According to previous studies, tocopherols are antioxidants involved in the photoprotection of plants and, for this reason, their content increases in plants exposed to adverse environmental conditions that induce oxidative stress (Havaux, Eymery, Porfirova, Rey, \& Dörmann, 2005).

The results of this study are in accordance with the information available in the literature, since $\alpha$-tocopherol was the only isoform detected in cardoon seeds $(1.83-6.7 \mathrm{mg} / 100 \mathrm{~g} \mathrm{dw}$ ) (Mandim, Dias et al., 2020; Petropoulos et al., 2019), as well as in grain oils of different cardoon genotypes (25.1 - 54.6 mg/100 g dw) (Maccarone et al., 1999). The reduced number of tocopherol isoforms has also been described in other plant tissues of cardoon, including bracts (Mandim, Giannoulis et al., 2020) and heads (Mandim, Petropoulos, Giannoulis et al., 2020), with the $\alpha$ isoform being the most commonly identified. This finding suggests that the tocopherols profile can be related to the plant part and
Table 2

Tocopherols, lipids and fatty acids composition of Cynara cardunculus L. var altilis seeds collected at different maturity stages.

\begin{tabular}{|c|c|c|c|c|}
\hline & S1 & $\mathrm{S} 2$ & S3 & S4 \\
\hline $\begin{array}{l}\alpha \text {-Tocopherol (mg/ } \\
100 \mathrm{~g} \mathrm{dw})\end{array}$ & $\begin{array}{l}2.20 \pm \\
0.01^{\mathrm{c}}\end{array}$ & $\begin{array}{l}2.23 \pm \\
0.01^{\mathrm{c}}\end{array}$ & $\begin{array}{l}2.51 \pm \\
0.01^{\mathrm{b}}\end{array}$ & $\begin{array}{l}29.62 \pm \\
0.05^{\mathrm{a}}\end{array}$ \\
\hline $\begin{array}{l}\text { Total lipid fraction (g/ } \\
100 \mathrm{~g} \mathrm{dw})\end{array}$ & $\begin{array}{l}6.78 \pm \\
0.01^{\mathrm{d}}\end{array}$ & $\begin{array}{l}19.04 \pm \\
0.01^{b}\end{array}$ & $\begin{array}{l}16.69 \pm \\
0.07^{c}\end{array}$ & $23 \pm 1^{a}$ \\
\hline \multicolumn{5}{|c|}{ Fatty acids (relative percentage, \%) } \\
\hline C6:0 & $\begin{array}{l}0.019 \pm \\
0.001^{\mathrm{b}}\end{array}$ & $\begin{array}{l}0.028 \pm \\
0.001^{\mathrm{b}}\end{array}$ & $\begin{array}{l}0.026 \pm \\
0.001^{\mathrm{b}}\end{array}$ & $16.3 \pm 0.4^{a}$ \\
\hline $\mathrm{C} 8: 0$ & $\begin{array}{l}0.018 \pm \\
0.001^{\mathrm{b}}\end{array}$ & $\begin{array}{l}0.014 \pm \\
0.001^{\mathrm{b}}\end{array}$ & $\begin{array}{l}0.014 \pm \\
0.001^{\mathrm{b}}\end{array}$ & $3.0 \pm 0.1^{a}$ \\
\hline $\mathrm{C} 10: 0$ & $\begin{array}{l}0.022 \pm \\
0.001^{\mathrm{b}}\end{array}$ & $\begin{array}{l}0.017 \pm \\
0.001^{\mathrm{c}}\end{array}$ & $\begin{array}{l}0.015 \pm \\
0.001^{\mathrm{d}}\end{array}$ & $\begin{array}{l}0.151 \pm \\
0.002^{a}\end{array}$ \\
\hline $\mathrm{C} 11: 0$ & $\begin{array}{l}0.027 \pm \\
0.003^{b}\end{array}$ & $\begin{array}{l}0.035 \pm \\
0.001^{\mathrm{b}}\end{array}$ & $\begin{array}{l}0.028 \pm \\
0.002^{\mathrm{b}}\end{array}$ & $\begin{array}{l}0.67 \pm 0.03 \\
\mathrm{a}\end{array}$ \\
\hline C12:0 & $\begin{array}{l}0.033 \pm \\
0.001^{\mathrm{b}}\end{array}$ & $\begin{array}{l}0.027 \pm \\
0.001^{\mathrm{b}}\end{array}$ & $\begin{array}{l}0.015 \pm \\
0.001^{c}\end{array}$ & $\begin{array}{l}0.18 \pm 0.01 \\
\text { a }\end{array}$ \\
\hline C14:0 & $\begin{array}{l}0.181 \pm \\
0.004^{\mathrm{b}}\end{array}$ & $\begin{array}{l}0.14 \pm \\
0.01^{\mathrm{c}}\end{array}$ & $\begin{array}{l}0.123 \pm \\
0.001^{\mathrm{c}}\end{array}$ & $\begin{array}{l}0.59 \pm 0.02 \\
\mathrm{a}\end{array}$ \\
\hline C15:0 & $\begin{array}{l}0.063^{ \pm} \\
0.001^{\mathrm{b}}\end{array}$ & $\begin{array}{l}0.032 \pm \\
0.001\end{array}$ & $\begin{array}{l}0.038 \pm \\
0.001^{\mathrm{c}}\end{array}$ & $\begin{array}{l}0.125 \pm \\
0.001^{\mathrm{a}}\end{array}$ \\
\hline C16:0 & $\begin{array}{l}13.81 \pm \\
0.02^{\mathrm{b}}\end{array}$ & $11 \pm 1^{\mathrm{c}}$ & $11.5 \pm 0.3^{\mathrm{c}}$ & $\begin{array}{l}55.948 \pm \\
0.002^{\mathrm{a}}\end{array}$ \\
\hline C16:1 & $\begin{array}{l}0.185 \pm \\
0.006^{\mathrm{b}}\end{array}$ & $\begin{array}{l}0.135 \pm \\
0.004^{\mathrm{d}}\end{array}$ & $\begin{array}{l}0.162 \pm \\
0.004^{c}\end{array}$ & $\begin{array}{l}0.78 \pm 0.02 \\
\text { a }\end{array}$ \\
\hline $\mathrm{C} 17: 0$ & $\begin{array}{l}0.082 \pm \\
0.001^{b}\end{array}$ & $\begin{array}{l}0.068 \pm \\
0.001^{\mathrm{b}}\end{array}$ & $\begin{array}{l}0.069 \pm \\
0.001^{b}\end{array}$ & $\begin{array}{l}0.33 \pm 0.02 \\
\text { a }\end{array}$ \\
\hline C18:0 & $\begin{array}{l}3.289 \pm \\
0.001\end{array}$ & $3.6 \pm 0.1^{c}$ & $\begin{array}{l}4.42 \pm \\
0.04^{\mathrm{b}}\end{array}$ & $\begin{array}{l}16.39 \pm \\
0.01^{\mathrm{a}}\end{array}$ \\
\hline C18:1n9c & $\begin{array}{l}0.66 \pm \\
0.05^{\mathrm{b}}\end{array}$ & $\begin{array}{l}0.58 \pm \\
0.03^{\mathrm{c}}\end{array}$ & $\begin{array}{l}0.72 \pm \\
0.05^{\mathrm{b}}\end{array}$ & $\begin{array}{l}1.33 \pm 0.03 \\
\mathrm{a}\end{array}$ \\
\hline $\mathrm{C} 18: 2 \mathrm{n} 6 \mathrm{c}$ & $\begin{array}{l}76.79 \pm \\
0.07^{\mathrm{c}}\end{array}$ & $\begin{array}{l}83.3 \pm 0.5 \\
\text { a }\end{array}$ & $\begin{array}{l}82.0 \pm \\
0.2^{\mathrm{b}}\end{array}$ & $1.7 \pm 0.1^{d}$ \\
\hline $\mathrm{C} 18: 3 \mathrm{n} 3$ & $\begin{array}{l}4.060 \pm \\
0.001^{\mathrm{a}}\end{array}$ & $\begin{array}{l}0.120 \pm \\
0.001^{c}\end{array}$ & $\begin{array}{l}0.139 \pm \\
0.001^{b}\end{array}$ & $\begin{array}{l}0.07 \pm 0.01 \\
\mathrm{~d}\end{array}$ \\
\hline C20:0 & $\begin{array}{l}0.47 \pm \\
0.01^{\mathrm{b}}\end{array}$ & $\begin{array}{l}0.35 \pm \\
0.02^{\mathrm{c}}\end{array}$ & $\begin{array}{l}0.427 \pm \\
0.005^{\mathrm{b}}\end{array}$ & $1.8 \pm 0.1^{\mathrm{a}}$ \\
\hline C20:1 & $\begin{array}{l}0.120 \pm \\
0.004^{\mathrm{b}}\end{array}$ & $\begin{array}{l}0.13 \pm \\
0.01^{\mathrm{b}}\end{array}$ & $\begin{array}{l}0.08 \pm \\
0.01^{\mathrm{c}}\end{array}$ & $\begin{array}{l}0.49 \pm 0.01 \\
\mathrm{a}\end{array}$ \\
\hline C20:2 & $\begin{array}{l}0.180 \pm \\
0.004^{\mathrm{a}}\end{array}$ & $\begin{array}{l}0.24 \pm \\
0.02^{\mathrm{c}}\end{array}$ & $\begin{array}{l}0.20 \pm \\
0.01^{\mathrm{b}}\end{array}$ & $\begin{array}{l}0.12 \pm 0.01 \\
\mathrm{~d}\end{array}$ \\
\hline SFA & $\begin{array}{l}18.01 \pm \\
0.01^{\mathrm{b}}\end{array}$ & $\begin{array}{l}15.5 \pm 0.5 \\
d\end{array}$ & $16.7 \pm 0.3^{\mathrm{c}}$ & $95.5 \pm 0.2^{a}$ \\
\hline MUFA & $\begin{array}{l}0.96 \pm \\
0.1^{\mathrm{b}}\end{array}$ & $\begin{array}{l}0.84 \pm \\
0.03^{\mathrm{c}}\end{array}$ & $\begin{array}{l}0.96 \pm \\
0.05^{\mathrm{b}}\end{array}$ & $\begin{array}{l}2.60 \pm 0.05 \\
\mathrm{a}\end{array}$ \\
\hline PUFA & $81.0 \pm 0.1^{\mathrm{c}}$ & $\begin{array}{l}83.7 \pm 0.5 \\
\text { a }\end{array}$ & $\begin{array}{l}82.4 \pm \\
0.2^{\mathrm{b}}\end{array}$ & $1.9 \pm 0.1^{\mathrm{d}}$ \\
\hline PUFA/SFA & $\begin{array}{l}4.50 \pm \\
0.01^{\mathrm{c}}\end{array}$ & $5.4 \pm 0.2^{a}$ & $4.9 \pm 0.1^{b}$ & $\begin{array}{l}0.019 \pm \\
0.001^{d}\end{array}$ \\
\hline$n-6 / n-3$ & $\begin{array}{l}18.91 \pm \\
0.02^{\mathrm{d}}\end{array}$ & $694 \pm 4^{a}$ & $590 \pm 5^{b}$ & $25.1 \pm 0.5^{c}$ \\
\hline
\end{tabular}

Results are presented as mean \pm standard deviation. Different letters correspond to significant differences $(p<0.05)$. Fatty acids are expressed as relative percentage of each fatty acid. dw - dry weight; C6:0 - caproic acid; C8:0 - caprylic acid; C10:0 - capric acid; C11:0 - undecanoic acid; C12:0 - lauric acid; C14:0 myristic acid; C15:0 - pentadecanoic acid; C16:0 - palmitic acid; C16:1 - palmitoleic acid; C17:0 - heptadecanoic acid; C18:0 - stearic acid; C18:1n9 - oleic acid; C18:2n6c -linoleic acid; C18:3n3 - linolenic acid; C20:0 - arachidic acid; C20:1 - gadoleic acid; C20:2 - eicosadienoic acid; SFA - saturated fatty acids; MUFA - monounsaturated fatty acids; PUFA - polyunsaturated fatty acids; $n-6 /$ n-3: ratio of omega 6/omega 3 fatty acids.

is of great importance when it is intended to valorise crop by-products, as they can increase the added value of cardoon crop.

\subsection{Composition in fatty acids}

The total lipid content and the fatty acids composition of cardoon seeds are also presented in Table 2. The lipid content increased significantly ( $p$-value $<0.05$ ) with seed maturity, with sample S4 containing a 3.4 times higher lipid concentration than immature seeds (S1). Seventeen fatty acids were identified in all the studied stages of maturity, 
highlighting the presence of palmitic (C16:0, 11-55.948\%), stearic (C18:0, $3.289-16.39 \%)$, and linoleic (C18:2n6c, $1.7-83.3 \%$ ) acids, which presented higher relative percentages than the others. Polyunsaturated fatty acids (PUFA) were the most abundant class of fatty acids $(>80 \%$ ), followed by saturated fatty acids (SFA; $<20 \%$ ), while monounsaturated fatty acids (MUFA) represented $<1 \%$. This situation completely changed in sample S4, where SFAs were the most abundant class of fatty acids $(95.5 \%)$, followed by MUFAs $(2.60 \%)$ and PUFAs (1.9\%). The low content of unsaturated fatty acids in the more advanced state of maturation might be justified by the concurrence of oxidation reactions favoured by greater exposure to oxidizing conditions ( $\mathrm{Liu}, \mathrm{Lu}$, Yang, \& Bi, 2019). In previous studies, PUFAs were the class of fatty acids with the highest prevalence in cardoon seeds from different genotypes and capitula also collected at more advanced maturation states, followed by SFAs and MUFAs (Mandim, Petropoulos, Fernandes et al., 2020; Petropoulos et al., 2019). In this study it is verified that the maturity stage of cardoon seeds influences the composition and relative abundance of fatty acids, a finding that is in agreement with previous studies of our team, where the composition of other parts of cardoon are described (Mandim, Giannoulis et al., 2020; Mandim, Petropoulos, Fernandes et al., 2020). To the best of our knowledge, this is the first report describing the influence of the maturity stage on the fatty acids profile of cardoon seeds where, according to the obtained results, the lipid content increased with seed maturity progress. Regarding other lipophilic compounds, Ferreira-Dias, Gominho, Baptista, and Pereira (2018) described the presence of phytosterols in cardoon achenes collected in Sesimbra, Portugal, and demonstrated that the edaphoclimatic conditions influence these constituents.

\subsection{Composition in organic acids}

The results regarding the composition in organic acids of cardoon seeds in relation to their maturity stage are presented in Table 3. Oxalic, quinic, malic, citric, and fumaric acids were detected in all samples. The composition in organic acids varied throughout the maturation process, with statistically significant differences $(p$-value $<0.05)$ between

Table 3

Organic acids and free sugars composition of Cynara cardunculus L. var altilis seeds collected at different maturity stages.

\begin{tabular}{|c|c|c|c|c|}
\hline & S1 & S2 & S3 & S4 \\
\hline \multicolumn{5}{|c|}{ Organic acids $(g / 100 \mathrm{~g} \mathrm{dw})$} \\
\hline Oxalic acid & $\begin{array}{l}0.127 \pm \\
0.001^{\mathrm{a}}\end{array}$ & $\begin{array}{l}0.079 \pm \\
0.004^{\mathrm{b}}\end{array}$ & $\begin{array}{l}0.128 \pm \\
0.002^{\mathrm{a}}\end{array}$ & $0.13 \pm 0.01^{a}$ \\
\hline Quinic acid & $\operatorname{tr}$ & $\operatorname{tr}$ & $0.07 \pm 0.01 *$ & $0.05 \pm 0.01 *$ \\
\hline Malic acid & $\begin{array}{l}0.086 \pm \\
0.003 *\end{array}$ & $\operatorname{tr}$ & $\operatorname{tr}$ & $\operatorname{tr}$ \\
\hline Citric acid & $0.33 \pm 0.01^{\mathrm{a}}$ & $\begin{array}{l}0.052 \pm \\
0.002^{\mathrm{c}}\end{array}$ & $0.13 \pm 0.01^{\mathrm{b}}$ & n.d. \\
\hline Fumaric acid & $\operatorname{tr}$ & $\operatorname{tr}$ & $\operatorname{tr}$ & $\operatorname{tr}$ \\
\hline $\begin{array}{l}\text { Total organic } \\
\text { acids }\end{array}$ & $0.54 \pm 0.01^{a}$ & $\begin{array}{l}0.131 \pm \\
0.002^{c}\end{array}$ & $\begin{array}{l}0.329 \pm \\
0.003^{\mathrm{b}}\end{array}$ & $\begin{array}{l}0.03 \pm 0.003 \\
d\end{array}$ \\
\hline \multicolumn{5}{|c|}{ Free sugars $(g / 100 g d w)$} \\
\hline Fructose & $1.07 \pm 0.07^{\mathrm{a}}$ & $0.17 \pm 0.04^{\mathrm{b}}$ & n.d. & $0.05 \pm 0.01^{\mathrm{c}}$ \\
\hline Glucose & $0.34 \pm 0.05 *$ & n.d. & n.d. & $\begin{array}{l}0.082 \pm \\
0.004 *\end{array}$ \\
\hline Sucrose & $8.77 \pm 0.07^{\mathrm{a}}$ & $1.36 \pm 0.07^{\mathrm{b}}$ & $0.90 \pm 0.05^{\mathrm{c}}$ & $1.31 \pm 0.03^{\mathrm{b}}$ \\
\hline Trehalose & $\begin{array}{l}36.44 \pm 0.09 \\
\text { a }\end{array}$ & $0.17 \pm 0.06^{\mathrm{b}}$ & $0.21 \pm 0.06^{\mathrm{b}}$ & $0.16 \pm 0.02^{\mathrm{b}}$ \\
\hline Raffinose & n.d. & $0.91 \pm 0.05^{\mathrm{b}}$ & $0.90 \pm 0.01^{\mathrm{b}}$ & $1.3 \pm 0.1^{\mathrm{a}}$ \\
\hline Total & $46.61^{a}$ & $2.6 \pm 0.1^{c}$ & $\begin{array}{l}1.999 \pm \\
0.001^{\mathrm{d}}\end{array}$ & $2.9 \pm 0.1^{\mathrm{b}}$ \\
\hline
\end{tabular}

Results are presented as mean \pm standard deviation. Different letters correspond to significant differences $(p<0.05) . *$ Means statistical differences obtained by a $t$-student test, $p$-value $<0.01$. dw - dry weight; tr - traces; n.d. - not detected. Calibration curves for organic acids: oxalic acid $\left(\mathrm{y}=9106 \mathrm{x}+45.973, \mathrm{R}^{2}=\right.$ 0.9901); Quinic acid ( $\left.\mathrm{y}=610607 \mathrm{x}+46.061, \mathrm{R}^{2}=0.9995\right)$; Citric acid $(\mathrm{y}=$ $\left.1106 \times+45.682, \mathrm{R}^{2}=0.9997\right)$. samples. Seeds at early maturation stages (sample S1, PGS 6/7) revealed the highest abundance in organic acids $(0.54 \mathrm{~g} / 100 \mathrm{~g} \mathrm{dw})$, while sample S4 (PGS 8) had the lowest abundance $(0.03 \mathrm{~g} / 100 \mathrm{~g} \mathrm{dw})$. Citric acid revealed the highest amounts in samples S1 and S3, while S2 had the lowest content in oxalic acid. Cardoon seeds showed a similar composition of organic acids to that observed for cardoon heads and bracts (Mandim, Petropoulos, Fernandes et al., 2020; Mandim, Giannoulis et al., 2020), with higher levels of organic acids in immature tissues. Nevertheless, in this case, the seeds at earlier maturity stages were those that present a higher amount of organic acids, contrary to what was observed for cardoon bracts and heads, where tissues in later stages of maturity revealed a higher abundance of these compounds (Mandim, Petropoulos, Fernandes et al., 2020; Mandim, Giannoulis et al., 2020). As observed for seeds, oxalic acid was also the organic acid present in greater abundance in cardoon heads with higher degrees of maturity (Mandim, Petropoulos, Fernandes et al., 2020). Despite the complexity behind the fluctuation in organic acids content during plant development and maturation, it has been described that the organic acid content in the early stages of maturation is directly related to the supply of substrates for respiratory processes, in which citrate and malate play important roles (Batista-Silva et al., 2018). Thus, citrate and malate contents tend to decrease during ripening, which justifies the reduction in malic and citric acid contents observed in this study.

\subsection{Composition in free sugars}

The free sugars composition was also significantly ( $p$-value $<0.05$ ) influenced by the maturity stage (Table 3 ). Seeds of early maturity (sample S1) have 16 times more sugar content than the sample S4 at a more advanced grade of maturity (S1 - 46.61 and S4 - 2.9 g/100 g dw). Trehalose was the major sugar in cardoon seeds harvested at earlier stages ( $1 ; 36.44 \mathrm{~g} / 100 \mathrm{~g} \mathrm{dw}$ ), while sucrose was the sugar detected in the highest concentration $(0.90-1.36 \mathrm{~g} / 100 \mathrm{~g} \mathrm{dw})$ in the remaining samples. The presence of larger amounts of sugars in immature plant tissues (namely in the heads and bracts) has been previously described in the literature (Mandim, Petropoulos, Fernandes et al., 2020; Mandim, Giannoulis et al., 2020). This finding could be related to the formation of inulin and the translocation of carbohydrates to other plant parts, as well as to the consequent increased demands for osmolytes accumulation. These occurrences are essential for species to be able to withstand the stress conditions that arise throughout the growth cycle, especially at later plant growth stages, which coincide with flower initiation due to higher temperatures and exposure to solar irradiation (Mandim, Giannoulis et al., 2020).

\subsection{Composition in phenolic compounds}

The phenolic composition of cardoon seeds was also analysed in regard to maturity stage. The chromatographic data (retention time, wavelengths of maximum absorption, the fragmentation pattern, and pseudomolecular ion), as well as the quantification (mg/g extract) of the identified phenolic compounds are shown in Table 4. Fig. 1 shows a representative chromatogram of the phenolic profile. Six phenolic compounds were detected, all of them phenolic acid derivatives. The phenolic composition of different cardoon plant tissues has already been studied and is described in several reports. In particular, the compounds with peak numbers $\mathbf{1}$ and $\mathbf{2}$ (cis and trans 5 -O-caffeoylquinic acid) have been previously reported in cardoon tissues (Mandim, Dias et al., 2020; Mandim et al., 2021; Mandim, Petropoulos, Giannoulis et al., 2020; Petropoulos, Pereira, Tzortzakis et al., 2018). Similarly, peaks 3 and $\mathbf{4}$ (cis and trans 1,3-O-dicaffeyolquinic acid) were previously identified in various cardoon genotypes (Dias et al., 2018). Peak number 5 (3,4-Odicaffeoylquinic acid) was previously identified in cardoon heads, leaf midribs and petioles (Petropoulos, Pereira, Tzortzakis et al., 2018). Peak 6 (3,5-O-dicaffeoylquinic acid) was previously identified in cardoon bracts, seeds, and heads (Mandim, Dias et al., 2020; Mandim et al., 2021; 
Table 4

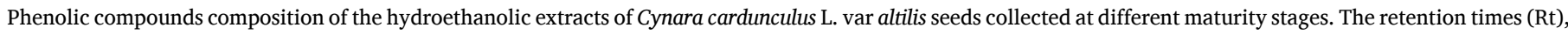
wavelengths of maximum absorption $\left(\lambda_{\max }\right)$ in the UV-Vis region, mass spectral data and tentative identification of phenolic compounds are presented.

\begin{tabular}{|c|c|c|c|c|c|c|c|c|c|}
\hline \multirow[t]{2}{*}{ Peak } & \multirow{2}{*}{$\begin{array}{l}\text { Rt } \\
(\min )\end{array}$} & \multirow{2}{*}{$\begin{array}{l}\lambda \max \\
(\mathrm{nm})\end{array}$} & \multirow{2}{*}{$\begin{array}{l}{[\mathrm{M}-\mathrm{H}]^{-}} \\
(\mathrm{m} / z)\end{array}$} & \multirow[t]{2}{*}{$\mathrm{MS}^{2}(m / z)$} & \multirow[t]{2}{*}{ Tentative identification } & \multicolumn{4}{|c|}{ Content (mg/g extract) } \\
\hline & & & & & & S1 & S2 & S3 & S4 \\
\hline 1 & 7.09 & 325 & 353 & 191(100),179(10),161(5),135(5) & cis 5-O-Caffeoylquinic acid & $\begin{array}{l}7.92 \pm 0.02 \\
\text { a }\end{array}$ & $\begin{array}{l}3.66 \pm \\
0.02^{\mathrm{c}}\end{array}$ & $\begin{array}{l}4.077 \pm \\
0.001^{\mathrm{b}}\end{array}$ & $\begin{array}{l}0.96 \pm 0.03 \\
*\end{array}$ \\
\hline 2 & 7.10 & 326 & 353 & 191(100),179(7),173(5),135(5) & $\begin{array}{l}\text { trans } 5 \text {-O-Caffeoylquinic } \\
\text { acid }\end{array}$ & n.d. & n.d. & n.d. & $2.7 \pm 0.1$ * \\
\hline 3 & 10.82 & 325 & 515 & $\begin{array}{l}355(70), 191(100), 179(48), 173 \\
(5), 161(5), 135(7)\end{array}$ & $\begin{array}{l}\text { cis } 1,3-O \text {-Dicaffeyolquinic } \\
\text { acid }\end{array}$ & n.d. & n.d. & n.d. & $\begin{array}{l}0.777 \pm \\
0.004 *\end{array}$ \\
\hline 4 & 11.49 & 325 & 515 & $\begin{array}{l}355(10), 191(100), 179(47), 173 \\
(10), 161(5), 135(6)\end{array}$ & $\begin{array}{l}\text { trans } 1,3-O- \\
\text { Dicaffeyolquinic acid }\end{array}$ & n.d. & n.d. & n.d. & $\begin{array}{l}0.68 \pm 0.03 \\
*\end{array}$ \\
\hline 5 & 18.78 & 324 & 515 & $\begin{array}{l}353(50), 191(43), 179(65), 173 \\
(100), 135(9)\end{array}$ & $\begin{array}{l}\text { 3,4-O-Dicaffeyolquinic } \\
\text { acid }\end{array}$ & $\begin{array}{l}0.507 \pm \\
0.002^{\mathrm{c}}\end{array}$ & $\begin{array}{l}1.935 \pm \\
0.001^{\mathrm{b}}\end{array}$ & $\begin{array}{l}2.44 \pm 0.01 \\
\mathrm{a}\end{array}$ & $6.2 \pm 0.1 *$ \\
\hline \multirow[t]{2}{*}{6} & 20.14 & 324 & 515 & $\begin{array}{l}353(50), 191(100), 179(15), 173 \\
(5), 135(5)\end{array}$ & $\begin{array}{l}\text { 3,5-O-Dicaffeyolquinic } \\
\text { acid }\end{array}$ & $14.8 \pm 0.1^{c}$ & $\begin{array}{l}34.25 \pm \\
0.04^{\mathrm{a}}\end{array}$ & $33.8 \pm 0.3^{\mathrm{b}}$ & $41 \pm 1 *$ \\
\hline & & & & & $\begin{array}{l}\text { Total phenolic } \\
\text { compounds }\end{array}$ & $23.2 \pm 0.1^{\mathrm{c}}$ & $\begin{array}{l}39.85 \pm \\
0.02^{\mathrm{b}}\end{array}$ & $40.4 \pm 0.3^{\mathrm{b}}$ & $53 \pm 2^{a}$ \\
\hline
\end{tabular}

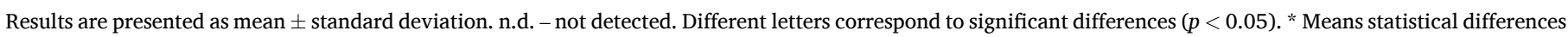
obtained by a $t$-student test ( $p$-value $<0.01)$.

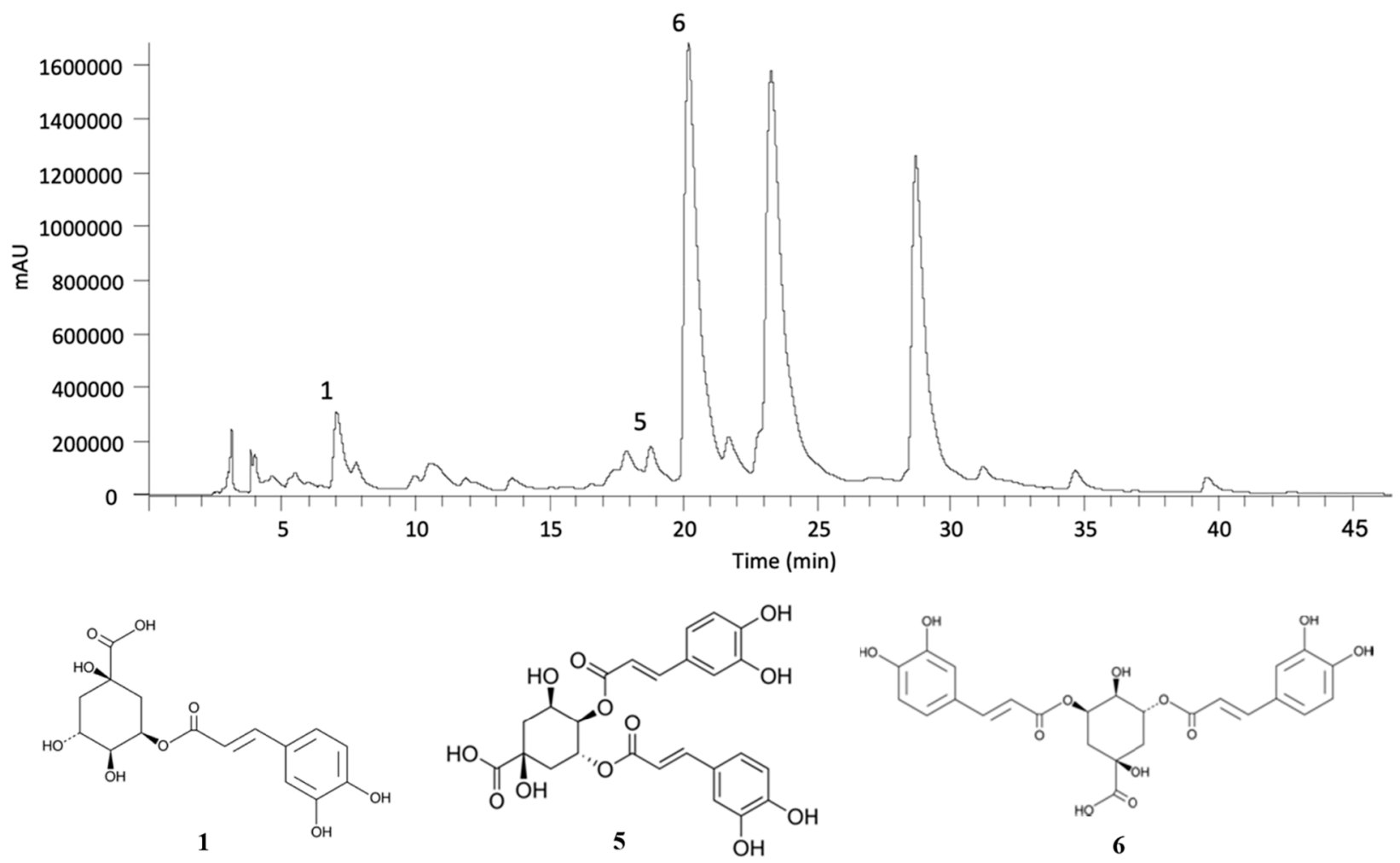

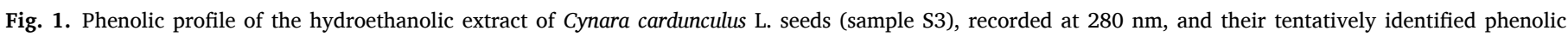
compounds. Peak numbers correspond to the compounds described in Table 4.

Mandim, Petropoulos, Giannoulis et al., 2020).

The content of phenolic compounds increased with increasing maturity. Cardoon seeds in more advanced maturation stage had a higher content of phenolic compounds than younger tissues $(53 \mathrm{mg} / \mathrm{g}$ extract for sample S4 compared to $23.2 \mathrm{mg} / \mathrm{g}$ extract for sample S1). In all the analysed samples, the presence of 3,5-O-dicaffeoylquinic acid (peak 6) was the one that stood out due to its high abundance in comparison with the rest of the identified phenolic acids. In addition to the effect of maturity stage on phenolic compounds composition, the polyphenolic profile in seeds also varied throughout the growth cycle. This influence was also verified in other cardoon parts such as capitula and bracts, where the amount of phenolic compounds was higher in younger tissues (Mandim et al., 2021; Mandim, Petropoulos, Giannoulis et al.,
2020). It has also been reported that different plant tissues of Cynara scolymus (receptacles, bracts, and floral stems) had a higher content of phenolic compounds in spring when compared with winter, while some of the compounds were not identified in both growing periods indicating significant differences in phenolic compounds profile (Lombardo et al., 2010). Besides the high impact of the maturity stage, the phenolic composition of cardoon can also be affected by intrinsic plant characteristics and edaphoclimatic conditions (Dias et al., 2018; Mandim, Dias et al., 2020; Petropoulos et al., 2019). The characterization of the species and the study of the effect that pre-harvest factors have on the chemical composition of cardoon are of great importance for its valorisation and a more efficient use, which can also contribute to the reduction of biowaste and to the circular economy and sustainable farming concept. 


\subsection{Bioactive properties}

\subsubsection{Antioxidant activity}

The obtained results are presented in Table 5. All the studied maturity states showed the ability to inhibit the oxidation process in both performed assays. All extracts had $\mathrm{IC}_{50}$ values higher than those demonstrated by the positive control, except for the $\$ 4$ sample in TBARS assay which revealed a greater antioxidant potential than the commercial antioxidant Trolox ( $\mathrm{IC}_{50}$ of $5 \mu \mathrm{g} / \mathrm{mL}$ for sample $S 4$ and $9.1 \mu \mathrm{g} / \mathrm{mL}$ for Trolox). The maturity stage had a statistically significant ( $p$-value $<$ 0.05 ) influence on the antioxidant activity of the extracts from the tested cardoon seed samples. For the TBARS assay, the $\mathrm{IC}_{50}$ values decreased (meaning that antioxidant potential increased) with the increasing seed maturity; sample S1 revealed the highest $\mathrm{IC}_{50}$ value $(160 \mu \mathrm{g} / \mathrm{mL})$ and sample S4 the lowest ( $\mathrm{IC}_{50}=5 \mu \mathrm{g} / \mathrm{mL}$ ). Moreover, for the OxHLIA assay, seeds collected at the principal growth stage (PGS 7/8 (S3)) were the ones that revealed the highest capacity to protect the erythrocytes from the haemolysis, with the lowest $\mathrm{IC}_{50}$ values $(37.7 \mu \mathrm{g} / \mathrm{mL}$ and $65 \mu \mathrm{g} / \mathrm{mL}$ for 60 and $120 \mathrm{~min}$, respectively), whereas sample $S 4$ was the one that demonstrated the lowest antioxidant potential ( $\mathrm{IC}_{50}$ of $146 \mu \mathrm{g} / \mathrm{mL}$ and $243 \mu \mathrm{g} / \mathrm{mL}$ for 60 and $120 \mathrm{~min}$, respectively).

The antioxidant activity of cardoon extracts (obtained with different solvents and extraction methods, such as maceration, infusion, and Soxhlet extraction) is one of the most studied bioactivities of this species (Ramos et al., 2014). In previous studies it has been shown that several factors can influence the antioxidant potential of this species, such as genetic background, plant tissue, stage of maturity, and growing location (Mandim, Petropoulos, Giannoulis et al., 2020; Petropoulos, Pereira, Tzortzakis et al., 2018). To the best of the authors knowledge, this is the first study that assesses the influence of the maturity stage on the antioxidant potential of cardoon seeds. In general, the ethanolic extracts of cardoon seeds had higher antioxidant potential than bracts and heads of the same genotype (Mandim et al., 2021; Mandim, Petropoulos, Fernandes et al., 2020), as they revealed lower $\mathrm{IC}_{50}$ values. Petropoulos, Pereira, Tzortzakis et al. (2018) studied the antioxidant capacity of different parts of cardoon (heads, petioles, leaf blades, leaf midribs, and seeds) and also found that the hydromethanolic extracts of seeds showed the greatest antioxidant capacity. In that study, the antioxidant activity of seeds in intermediate and advanced maturity stages (samples S2, S3, and S4) was higher than the one found in other studied plant parts $\left(\mathrm{EC}_{50}\right.$ values of seeds: $125 \mathrm{mg} / \mathrm{mL}$; heads: $295 \mathrm{mg} / \mathrm{mL}$; leaf midribs and petioles: $964 \mathrm{mg} / \mathrm{mL}$; leaf blades: $112 \mathrm{mg} / \mathrm{mL}$ ). There are several articles that mention that the antioxidant activity is mostly correlated with the content in phenolic compounds, although other compounds may also contribute (Mandim et al., 2019). In the present study, the content of phenolic compounds increased with maturity stage, as it was the case for the antioxidant activity determined by the TBARS assay. This fact suggests a positive correlation between the content in phenolic compounds and the TBARS formation inhibition. However, the same trend does not occur for the results obtained in the OxHLIA assay, suggesting that other classes of compounds may be associated with the demonstrated antioxidant activity for this particular method.

\subsubsection{Cytotoxic activity}

The obtained results for the evaluation of cardoon seeds cytotoxic activity are shown in Table 5. Results were presented as the extracts' concentration that causes $50 \%$ of cell proliferation inhibition $\left(\mathrm{GI}_{50}\right)$, so that the lower $\mathrm{GI}_{50}$ value implies higher cytotoxic activity of the sample.

Table 5

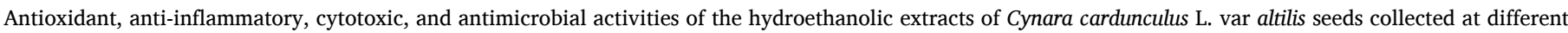
maturity stages.

\begin{tabular}{|c|c|c|c|c|c|c|c|c|c|c|c|c|}
\hline & \multicolumn{2}{|l|}{ S1 } & \multicolumn{2}{|l|}{ S2 } & \multicolumn{2}{|l|}{ S3 } & \multicolumn{2}{|l|}{ S4 } & \multicolumn{4}{|c|}{ Positive controls } \\
\hline Antioxidant activity $\left(\mathrm{IC}_{50}, \mu \mathrm{g} / \mathrm{mL}\right)$ & \multirow{2}{*}{\multicolumn{2}{|c|}{$160 \pm 1^{\mathrm{a}}$}} & \multirow{2}{*}{\multicolumn{2}{|c|}{$101.3 \pm 0.4^{\mathrm{b}}$}} & \multirow{2}{*}{\multicolumn{2}{|c|}{$92.2 \pm 0.3^{\mathrm{c}}$}} & \multirow{2}{*}{\multicolumn{2}{|c|}{$5.00 \pm 0.02^{d}$}} & \multicolumn{4}{|c|}{ Trolox } \\
\hline TBARS formation inhibition & & & & & & & & & $9.1 \pm$ & & & \\
\hline OxHLIA, $\Delta t=60 \mathrm{~min}$ & \multicolumn{2}{|c|}{$65 \pm 1^{\mathrm{b}}$} & \multicolumn{2}{|c|}{$43 \pm 1^{\mathrm{c}}$} & \multicolumn{2}{|c|}{$38 \pm 1^{\mathrm{c}}$} & \multicolumn{2}{|c|}{$146 \pm 2^{\mathrm{a}}$} & \multicolumn{4}{|c|}{$21.2 \pm 0.7$} \\
\hline OxHLIA, $\Delta t=120 \mathrm{~min}$ & \multicolumn{2}{|c|}{$109 \pm 2^{\mathrm{b}}$} & \multicolumn{2}{|c|}{$85 \pm 1^{c}$} & \multicolumn{2}{|c|}{$65 \pm 1^{d}$} & \multicolumn{2}{|c|}{$243 \pm 4^{\mathrm{a}}$} & \multicolumn{4}{|c|}{$41.1 \pm 0.8$} \\
\hline Cytotoxic activity $\left(\mathrm{GI}_{50}, \mu \mathrm{g} / \mathrm{mL}\right)$ & \multirow{2}{*}{\multicolumn{2}{|c|}{$>400$}} & \multirow{2}{*}{\multicolumn{2}{|c|}{$362 \pm 14^{\mathrm{a}}$}} & \multirow{2}{*}{\multicolumn{2}{|c|}{$332 \pm 15^{\mathrm{b}}$}} & & \multicolumn{4}{|c|}{ Ellipticine } \\
\hline MCF-7 (breast carcinoma) & & & & & & & $138=$ & & 1.21 & & & \\
\hline NCI-H460 (lung carcinoma) & \multicolumn{2}{|l|}{$>400$} & \multicolumn{2}{|c|}{$>400$} & \multicolumn{2}{|c|}{$>400$} & $200=$ & & $0.9 \pm$ & & & \\
\hline HeLa (cervical carcinoma) & $>400$ & & $369 \pm$ & & $360 \pm$ & & $116=$ & & 1.03 & & & \\
\hline HepG2 (hepatocellular carcinoma) & $350 \pm$ & & $>400$ & & $257 \pm$ & & $97 \pm$ & & 1.10 & & & \\
\hline PLP2 (porcine liver primary cells) & $>400$ & & $>400$ & & $>400$ & & $216=$ & & $2.3 \pm$ & & & \\
\hline Anti-inflammatory activity $\left(\mathrm{IC}_{50}, \mu \mathrm{g} / \mathrm{mL}\right)$ & & & & & & & & & Dexar & lasone & & \\
\hline RAW 246.7 (murine macrophage cells) & $>400$ & & $>400$ & & $>400$ & & $148=$ & & $16 \pm$ & & & \\
\hline & & & & & & & & & Strep & ycin & Amp & \\
\hline Antibacterial activity (mg/mL) & MIC & MBC & MIC & MBC & MIC & MBC & MIC & MBC & MIC & MBC & MIC & MBC \\
\hline Bacillus cereus & 1.54 & 3.06 & 0.80 & 1.60 & 0.80 & 1.60 & 1.18 & 2.35 & 0.10 & 0.20 & 0.25 & 0.40 \\
\hline Staphylococcus aureus & 3.06 & 6.12 & 3.21 & 3.21 & 0.80 & 1.60 & 2.35 & 4.71 & 0.04 & 0.10 & 0.25 & 0.45 \\
\hline Listeria monocytogenes & 3.06 & 6.12 & 3.21 & 3.21 & 1.60 & 3.19 & 2.35 & 4.71 & 0.20 & 0.30 & 0.40 & 0.50 \\
\hline Enterobacter cloacae & 3.06 & 6.12 & 3.21 & 3.21 & 0.80 & 1.60 & 2.35 & 4.71 & 0.20 & 0.30 & 0.25 & 0.50 \\
\hline Escherichia coli & 3.06 & 6.12 & 3.21 & 3.21 & 0.80 & 1.60 & 1.18 & 2.35 & 0.20 & 0.30 & 0.40 & 0.50 \\
\hline Salmonella Typhimurium & 3.06 & 6.12 & 3.21 & 3.21 & 0.80 & 1.60 & 2.35 & 4.71 & 0.20 & 0.30 & 0.75 & 1.20 \\
\hline & & & & & & & & & Ketoc & zole & Bifon & \\
\hline Antifungal activity (mg/mL) & MIC & MFC & MIC & MFC & MIC & MFC & MIC & MFC & MIC & MFC & MIC & MFC \\
\hline Aspergillus fumigatus & 0.51 & 1.02 & 0.53 & 1.07 & 0.53 & 1.06 & 0.89 & 1.77 & 0.25 & 0.50 & 0.15 & 0.20 \\
\hline Aspergillus versicolor & 0.51 & 1.02 & 0.53 & 1.07 & 0.27 & 0.53 & 0.89 & 1.77 & 0.2 & 0.5 & 0.1 & 0.2 \\
\hline Aspergillus niger & 1.02 & 2.04 & 1.07 & 2.14 & 1.06 & 2.13 & 1.77 & 3.55 & 0.2 & 0.5 & 0.15 & 0.2 \\
\hline Penicillium funiculosum & 0.51 & 1.02 & 0.53 & 1.07 & 1.06 & 2.13 & 0.89 & 1.77 & 0.2 & 0.5 & 0.2 & 0.25 \\
\hline Penicillium ochrochloron & 0.51 & 1.02 & 0.53 & 1.07 & 0.53 & 1.06 & 1.77 & 3.55 & 1.0 & 1.5 & 0.2 & 0.25 \\
\hline Penicillium verrucosum var. cyclopium & 0.51 & 1.02 & 0.53 & 1.07 & 1.06 & 2.13 & 3.55 & 7.10 & 0.2 & 0.3 & 0.1 & 0.2 \\
\hline
\end{tabular}

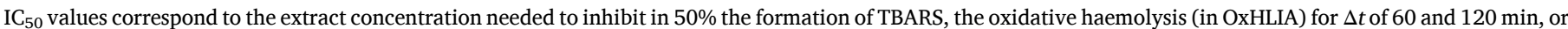

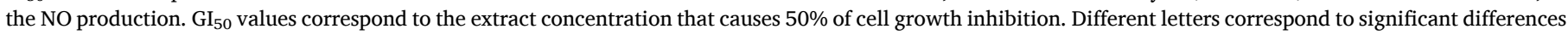

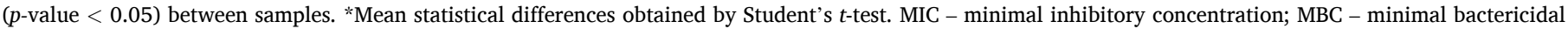
concentration; MFC - minimal fungicidal concentration. Positive controls: Streptomycin, Ampicillin, Ketoconazole and Bifonazole. 
The extract obtained from seeds collected at the latest maturity stage (S4) presented the lower $\mathrm{GI}_{50}$ values $(97-216 \mu \mathrm{g} / \mathrm{mL})$ for all the tested cell lines when compared with the remaining samples, and therefore had the higher cytotoxic potential. Among the tested cell lines, the lung carcinoma cells (NCI-H460) were the ones that demonstrated the lower susceptibility to the tested extracts; in addition, only the sample S4 demonstrated activity against this tumour cell line $\left(\mathrm{GI}_{50}=200 \mu \mathrm{g} / \mathrm{mL}\right)$.

The influence of the maturity stage on the cytotoxic potential of cardoon has been studied in capitula (heads) and bracts. Contrary to what was observed for seeds, samples of heads and bracts at younger maturity stages revealed higher cytotoxic potential (Mandim et al., 2021; Mandim, Petropoulos, Giannoulis et al., 2020). This could be attributed to compositional differences among plant parts, since several compounds may exhibit bioactive properties that may differ depending on the plant tissue chemical profile (Petropoulos, Pereira, Tzortzakis et al., 2018). Ramos et al. (2017) analysed the anticarcinogenic effect of floret samples from the variety altilis against triple-negative breast cancer (TNBC) and observed anti-proliferative effects. Several authors have correlated this bioactivity with the content of phytochemicals with anticarcinogenic effects, including phenolic compounds (Gostin \& Waisundara, 2019). To the best of the authors' knowledge, this is the first study addressing the influence of the maturity stage on the cytotoxic potential of cardoon seeds.

\subsubsection{Hepatotoxic activity}

The results of hepatotoxic activity of the cardoon seed extracts are presented in Table 5 . Three of the samples did not show hepatotoxicity at the tested concentrations ( $\mathrm{GI}_{50}$ values $>400 \mu \mathrm{g} / \mathrm{mL}$ ), while sample S4 revealed an $\mathrm{GI}_{50}$ value of $216 \mu \mathrm{g} / \mathrm{mL}$. Overall, the results revealed the cytotoxic potential of cardoon seeds for tumour cells, which could be used as a source of compounds of pharmaceutical interest and without safety concerns related to possible hepatotoxic effects. Previous works have also reported the absence of hepatotoxicity for cardoon extracts, namely from seeds separated according to the tissue viability (Mandim, Dias et al., 2020), as well as from heads at intermediate maturation stages (Mandim, Petropoulos, Giannoulis et al., 2020), and bracts at younger maturation stages (Mandim et al., 2021).

\subsubsection{Anti-inflammatory activity}

The results are presented in Table 5 as the extract concentration needed to inhibit by $50 \%$ the NO production. The sample collected at the latest growth stage 8 (S4) was the only that showed anti-inflammatory capacity, with an $\mathrm{IC}_{50}$ value of $148 \mu \mathrm{g} / \mathrm{mL}$. Although studies on the anti-inflammatory potential of cardoon plant parts, and particularly those of seeds, are very scarce, the results obtained are in agreement with the available literature. Mandim, Dias et al. (2020) evaluated the anti-inflammatory potential of viable and non-viable cardoon seeds and none of the samples showed such activity ( $\mathrm{IC}_{50}>400 \mu \mathrm{g} / \mathrm{mL}$ ). Also, Salem et al. (2017) studied the anti-inflammatory potential of cardoon leaf extracts, using the in vivo experimental Carr model, and verified that these extracts had the capacity to inhibit the production of mediators of the inflammatory process, such as prostaglandin, histamine, and serotonin. To the best of authors knowledge, this is the first report which studies the anti-inflammatory capacity of cardoon seed extracts harvested at different maturity stages.

\subsubsection{Antimicrobial activity}

The antibacterial and antifungal potential of cardoon seeds were assessed against six bacteria and six fungi strains. The obtained results are presented in Table 5 as the minimal inhibitory (MIC), bactericidal (MBC), and fungicidal (MFC) concentrations. All the tested extracts showed ability to inhibit the microbial growth and caused death of the bacterial and fungi species tested. As described in previous studies with different plant tissues of cardoon, Gram-positive bacteria are more susceptible than Gram-negative bacteria to seed extracts (Mandim et al., 2021; Scavo et al., 2019). Bacillus cereus was the more susceptible bacteria (MIC values between 0.80 and $1.54 \mathrm{mg} / \mathrm{mL}$ ), whereas L. monocytogenes was the bacterium that showed less susceptibility, with higher MIC values in sample S3, when compared to the other microorganisms tested (MIC values between 1.60 and $3.21 \mathrm{mg} / \mathrm{mL}$ ). The sample collected at the principal growth stage $7 / 8$ (S3) was the one that showed the highest antibacterial potential, since it presented the lowest MIC values (MIC values between 0.80 and $1.60 \mathrm{mg} / \mathrm{mL}$ ). None of the extracts tested revealed higher antibacterial activity than the positive controls used (commercial antibiotics, i.e., streptomycin and ampicillin). The seeds analysed in this work presented higher antibacterial potential than other parts of cardoon previously tested, namely the inflorescences of different genotypes (Dias et al., 2018), heads (Mandim, Petropoulos, Giannoulis et al., 2020) or bracts (Mandim et al., 2021), as well as viable and non-viable seeds previously analysed harvested in Viseu, Portugal (Mandim, Dias et al., 2020). These results pointed to the influence that different plant tissues, as well as the genetic background, maturity stage, and growing location may have on the biological proprieties of the species, as well as the presence and amount of some classes of bioactive compounds.

The antifungal potential of cardoon seeds was also assessed. The obtained MIC and MFC values are presented in Table 5. The sample collected at early maturity stage (sample S1) revealed the lowest MIC values for all the fungi strains tested (MIC values between 0.51 and 1.02 $\mathrm{mg} / \mathrm{mL}$ ), except for A. versicolor, for which sample S3 showed higher antifungal activity (MIC $=0.27 \mathrm{mg} / \mathrm{mL}$ against the $0.51 \mathrm{mg} / \mathrm{mL}$ of sample S1). Although the sample S4 showed antifungal activity, it was the one that revealed the lower activity, with the highest MIC and MFC values compared to the other studied extracts. Several articles referred to the antifungal potential associated with cardoon seeds and also reported that maturity stage may influence the antimicrobial potential of cardoon heads and bracts (Mandim, Petropoulos, Giannoulis et al., 2020; Mandim et al., 2021), as well as the plant tissue under analysis (Petropoulos, Pereira, Ntatsi et al., 2018).

\section{Conclusion}

Cardoon seeds are seldom used since they are mostly implemented for oil extraction. The study of the chemical and biological properties of this tissue is very important, since it allows adding value to the species by valorising all its constituents, as well as exploring its most advantageous use. According to the obtained results, the chemical composition and biological potential of cardoon seeds is greatly influenced by the maturity stage. The content in phenolic compounds increased with maturity progress. Caffeoylquinic and dicaffeoylquinic acids were the major detected polyphenols. Seeds collected in more advanced maturity stages (sample S4) revealed the highest content in phenolic compounds, as also the highest content in tocopherols and lipid fraction. The same sample (S4) also demonstrated higher capacity to inhibit the lipid peroxidation, the nitric oxide production, and the proliferation of tumour cells. In contrast, sample S3 was the one that revealed the highest capacity to inhibit the oxidative haemolysis. Regarding the antibacterial and antifungal activities, all the tested extracts were capable to inhibit the growth of the tested bacteria and fungi. Sample S3 revealed the greatest antibacterial activity, whereas sample $S 1$ had the highest antifungal activity.

The study of unexplored plant species, as well as their further characterization is of utmost importance. The present work allowed to characterize the chemical composition and the bioactive properties of cardoon seeds at a more profound level and studied how maturity stage may influence these parameters. Given their high bioactive and phytochemical potential, their use as a source of valuable biomolecules that can be applied in different types of products and varied applications should be further explored to increase the added value of the species. 


\section{Declaration of Competing Interest}

The authors declare that they have no known competing financial interests or personal relationships that could have appeared to influence the work reported in this paper.

\section{Acknowledgements}

The authors are grateful to the Foundation for Science and Technology (FCT, Portugal) for financial support by national funds FCT/ MCTES to CIMO (UIDB/00690/2020); for the F. Mandim PhD grant (SFRH/BD/146614/2019) and the J. Pinela (CEECIND/01001/2018), and M.I. Dias and L. Barros contracts through the individual and institutional scientific employment program-contract. The authors are also grateful to the project TRANSCoLAB (0612_TRANS_CO_LAB_2_P), to the European Regional Development Fund (ERDF) through the Regional Operational Program North 2020, within the scope of Project GreenHealth, Norte-01-0145-FEDER-000042, and Science and Technological Development of the Republic of Serbia (451-03-68/ 2020-14/200007). The GIP-USAL is funded by Junta de Castilla y León (Spain) through the Project SA093P20 and the Strategic Research Program for Units of Excellence (ref. CLU-2018-04).

\section{References}

Almeida, C. M., \& Simões, I. (2018). Cardoon-based rennets for cheese production. Applied Microbiology and Biotechnology, 102, 4675-4686. https://doi.org/10.1007/ s00253-018-9032-3.

Amira, A. B., Blecker, C., Richel, A., Arias, A. A., Fickers, P., Francis, F., ... Attia, H. (2018). Influence of the ripening stage and the lyophilization of wild cardoon flowers on their chemical composition, enzymatic activities of extracts and technological properties of cheese curds. Food Chemistry, 245, 919-925. https://doi. org/10.1016/j.foodchem.2017.11.082.

AOAC, Official methods of analysis of AOAC international ed. W. George and G. W. Latimer Jr., AOAC International, Gaithersburg, MD, 20th ed, 2016.

Archontoulis, S. V., Struik, P. C., Vos, J., \& Danalatos, N. G. (2010). Phenological growth stages of Cynara cardunculus: Codification and description according to the BBCH scale. Annals of Applied Biology, 156, 253-270. https://doi.org/10.1111/j.17447348.2009.00384.x.

Barbanera, M., Castellini, M., Tasselli, G., Turchetti, B., Cotana, F., \& Buzzini, P. (2021). Prediction of the environmental impacts of yeast biodiesel production from cardoon stalks at industrial scale. Fuel, 283, 118967. https://doi.org/10.1016/j. fuel.2020.118967.

Bartocci, P., Bidini, G. I., Cotana, F., \& Fantozzi, F. (2016). Energy Balance of cardoon (Cynara cardunculus L.) cultivation and pyrolysis. Perennial Biomass Crops for a Resource-Constrained. World, 1-313. https://doi.org/10.1007/978-3-319-44530-4.

Batista-Silva, W., Nascimento, V. L., Medeiros, D. B., Nunes-Nesi, A., Ribeiro, D. M., Zsögön, A., \& Araújo, W. L. (2018). Modifications in organic acid profiles during fruit development and ripening: Correlation or causation? Frontiers in Plant Science, 871 1-20. https://doi.org/10.3389/fpls.2018.01689.

Bessada, S. M. F., Barreira, J. C. M., Barros, L., Ferreira, I. C. F. R., \& Oliveira, M. B. P. P. (2016). Phenolic profile and antioxidant activity of Coleostephus myconis (L.) Rchb.f.: An underexploited and highly disseminated species. Industrial Crops and Products, 89, 45-51. https://doi.org/10.1016/j.indcrop.2016.04.065.

Brás, T., Guerreiro, O., Duarte, M. F., \& Neves, L. A. (2015). Impact of extraction parameters and concentration by nanofiltration on the recovery of phenolic compounds from Cynara cardunculus var. altilis: Assessment of antioxidant activity. Industrial Crops and Products, 137-142.

Chihoub, W., Dias, M. I., Barros, L., Calhelha, R. C., Alves, M. J., Harzallah-Skhiri, F., \& Ferreira, I. C. F. R. (2019). Valorisation of the green waste parts from turnip, radish and wild cardoon: Nutritional value, phenolic profile and bioactivity evaluation. Food Research International, 126, 108651. https://doi.org/10.1016/j. foodres.2019.108651.

Conceição, C., Martins, P., Alvarenga, N., Dias, J., Lamy, E., Garrido, L., ... Duarte, M. F. (2012). Cynara cardunculus: Use in cheesemaking and pharmaceutical applications. In Technological Approaches for Novel Applications in Dairy Processing (pp. 73-107). 10.1016/j.colsurfa.2011.12.014.

Dias, M. I., Barros, L., Barreira, J. C. M., Alves, M. J., Barracosa, P., \& Ferreira, I. C. F. R. (2018). Phenolic profile and bioactivity of cardoon (Cynara cardunculus L.) inflorescence parts: Selecting the best genotype for food applications. Food Chemistry, 268, 196-202. https://doi.org/10.1016/j.foodchem.2018.06.081.

Dias, M. I., Barros, L., Morales, P., Sánchez-Mata, M. C., Oliveira, M. B. P. P., \& Ferreira, I. C. F. R. (2015). Nutritional parameters of infusions and decoctions obtained from Fragaria vesca L. roots and vegetable parts. LWT - Food Science and Technology, 62, 32-38. https://doi.org/10.1016/j.lwt.2015.01.034.

do Carmo, M. A. V., Pressete, C. G., Marques, M. J., Granato, D., \& Azevedo, L. (2018) Polyphenols as potential antiproliferative agents: Scientific trends. Current Opinion in Food Science, 24, 26-35. https://doi.org/10.1016/j.cofs.2018.10.013.
Durazzo, A., Foddai, M., Temperini, A., Azzini, E., Venneria, E., Lucarini, M., Maiani, G. (2013). Antioxidant properties of seeds from lines of artichoke, cultivated cardoon and wild cardoon. Antioxidants, 2, 52-61. https://doi.org/10.3390/ antiox2020052.

Ferreira-Dias, S., Gominho, J., Baptista, I., \& Pereira, H. (2018). Pattern recognition of cardoon oil from different large-scale field trials. Industrial Crops and Products, 118, 236-245. https://doi.org/10.1016/j.indcrop.2018.03.038.

Gostin, A. I., \& Waisundara, V. Y. (2019). Edible flowers as functional food: A review on artichoke (Cynara cardunculus L.). Trends in Food Science and Technology, 86, 381-391. https://doi.org/10.1016/j.tifs.2019.02.015.

Havaux, M., Eymery, F., Porfirova, S., Rey, P., \& Dörmann, P. (2005). Vitamin E protects against photoinhibition and photooxidative stress in Arabidopsis thaliana. Plant Cell, 17, 3451-3469. https://doi.org/10.1105/tpc.105.037036.

Kammoun, M., Koubaa, I., Ben Ali, Y., Jarraya, R., Gargouri, Y., Damak, M., \& Bezzine, S. (2010). Inhibition of pro-inflammatory secreted phospholipase A2 by extracts from Cynara cardunculus L. Applied Biochemistry and Biotechnology, 162, 662-670. https:// doi.org/10.1007/s12010-009-8849-8.

Liu, W., Lu, G., Yang, G., \& Bi, Y. (2019). Improving oxidative stability of biodiesel by cistrans isomerization of carbon-carbon double bonds in unsaturated fatty acid methyl esters. Fuel, 242, 133-139. https://doi.org/10.1016/j.fuel.2018.12.132.

Lombardo, S., Pandino, G., Mauromicale, G., Knödler, M., Carle, R., \& Schieber, A. (2010). Influence of genotype, harvest time and plant part on polyphenolic composition of globe artichoke [Cynara cardunculus L. var. scolymus (L.) Fiori]. Food Chemistry, 119, 1175-1181. https://doi.org/10.1016/j.foodchem.2009.08.033.

Maccarone, E., Fallico, B., Fanella, F., Mauromicale, G., Raccuia, S. A., \& Foti, S. (1999). Possible alternative utilization of Cynara spp. II. Chemical characterization of their grain oil. Industrial Crops and Products, 10, 229-237. https://doi.org/10.1016/ S0926-6690(99)00027-8.

Mandim, F., Barros, L., Calhelha, R. C., Abreu, R. M. V., Pinela, J., Alves, M. J., Ferreira, I. C. F. R. (2019). Calluna vulgaris (L.) Hull: Chemical characterization, evaluation of its bioactive properties and effect on the vaginal microbiota. Food and Function, 10, 78-89. https://doi.org/10.1039/C8FO01910J.

Mandim, F., Dias, M. I., Pinela, J., Barracosa, P., Ivanov, M., Stojkovic, D., Ferreira, I. C. F. R. (2020). Chemical composition and in vitro biological activities of cardoon (Cynara cardunculus L. var. altilis DC.) seeds as influenced by viability. Food Chemistry, 323, Article 126838. https://doi.org/10.1016/j.foodchem.2020.126838.

Mandim, F., Giannoulis, K. D., Santos-Buelga, C., Ferreira, I. C. F. R., \& Barros, L. (2020). Chemical composition of Cynara cardunculus L. var. altilis bracts cultivated in Central Greece: The impact of harvesting time. Agronomy, 10. https://doi.org/10.3390/ agronomy10081088.

Mandim, F., Petropoulos, S. A., Dias, M. I., Pinela, J., Kostic, M., Soković, M., Barros, L. (2021). Seasonal variation in bioactive properties and phenolic composition of cardoon (Cynara cardunculus var. altilis) bracts. Food Chemistry, 336, 127744. https://doi.org/10.1016/j.foodchem.2020.127744.

Mandim, F., Petropoulos, S. A., Fernandes, Â., Santos-Buelga, C., Ferreira, I. C. F. R., \& Barros, L. (2020). Chemical composition of Cynara cardunculus L. var. altilis heads: The impact of harvesting time. Agronomy, 10,1-15. https://doi.org/10.3390/ agronomy10081088.

Mandim, F., Petropoulos, S. A., Giannoulis, K. D., Dias, M. I., Fernandes, Â., Pinela, J., .. Ferreira, I. C. F. R. (2020). Seasonal variation of bioactive properties and phenolic composition of Cynara cardunculus var. altilis. Food Research International, 134, Article 109281. https://doi.org/10.1016/j.foodres.2020.109281.

Mirpoor, S. F., Giosafatto, C. V. L., \& Porta, R. (2021). Biorefining of seed oil cakes as industrial co-streams for production of innovative bioplastics. A review. Trends in Food Science and Technology, 109, 259-270. https://doi.org/10.1016/j. tifs.2021.01.014.

Pereira, C., Barros, L., Carvalho, A. M., Santos-Buelga, C., \& Ferreira, I. C. F. R. (2015). Infusions of artichoke and milk thistle represent a good source of phenolic acids and flavonoids. Food and Function, 6, 55-61. https://doi.org/10.1039/C4FO00834K.

Petropoulos, S., Fernandes, Â., Pereira, C., Tzortzakis, N., Vaz, J., Soković, M., Ferreira, I. C. F. R. (2019). Bioactivities, chemical composition and nutritional value of Cynara cardunculus L. seeds. Food Chemistry, 289, 404-412. https://doi.org/ 10.1016/j.foodchem.2019.03.066.

Petropoulos, S. A., Pereira, C., Ntatsi, G., Danalatos, N., Barros, L., \& Ferreira, I. C. F. R. (2018). Nutritional value and chemical composition of Greek artichoke genotypes. Food Chemistry, 267, 296-302. https://doi.org/10.1016/j.foodchem.2017.01.159.

Petropoulos, S. A., Pereira, C., Tzortzakis, N., Barros, L., \& Ferreira, I. C. F. R. (2018) Nutritional value and bioactive compounds characterization of plant parts from Cynara cardunculus L. (Asteraceae) cultivated in central Greece. Frontiers in Plant Science, 9, 1-12. https://doi.org/10.3389/fpls.2018.00459.

Ramos, P. A. B., Guerra, Â. R., Guerreiro, O., Santos, S. A. O., Oliveira, H., Freire, C. S. R., ... Duarte, M. F. (2017). Antiproliferative effects of Cynara cardunculus L. var. altilis (DC) lipophilic extracts. International Journal of Molecular Sciences, 18, 63. https:// doi.org/10.3390/ijms18010063.

Ramos, P. A. B., Santos, S. A. O., Guerra, Â. R., Guerreiro, O., Freire, C. S. R., Rocha, S. M., ... Silvestre, A. J. D. (2014). Phenolic composition and antioxidant activity of different morphological parts of Cynara cardunculus L. var. altilis (DC). Industrial Crops and Products, 61, 460-471. https://doi.org/10.1016/j. indcrop. 2014.07.042.

Salekzamani, S., Ebrahimi-Mameghani, M., \& Rezazadeh, K. (2019). The antioxidant activity of artichoke (Cynara scolymus): A systematic review and meta-analysis of animal studies. Phytotherapy Research, 33, 55-71. https://doi.org/10.1002/ptr.6213.

Salem, M. B., Affes, H., Athmouni, K., Ksouda, K., Dhouibi, R., Sahnoun, Z., Zeghal, K. M. (2017). Chemicals compositions, antioxidant and anti-inflammatory activity of Cynara scolymus leaves extracts, and analysis of major bioactive 
polyphenols by HPLC. Evidence-Based Complementary and Alternative Medicine, 2017. https://doi.org/10.1155/2017/4951937.

Scavo, A., Pandino, G., Restuccia, C., Parafati, L., Cirvilleri, G., \& Mauromicale, G.

(2019). Antimicrobial activity of cultivated cardoon (Cynara cardunculus L. var. altilis
DC.) leaf extracts against bacterial species of agricultural and food interest. Industrial

Crops and Products, 129, 206-211. https://doi.org/10.1016/j.indcrop.2018.12.005. Zayed, A., Serag, A., \& Farag, M. A. (2020). Cynara cardunculus L.: Outgoing and

potential trends of phytochemical, industrial, nutritive and medicinal merits. Journal of Functional Foods, 69, Article 103937. https://doi.org/10.1016/j.jff.2020.103937. 